The International Journal of Multimedia \& Its Applications (IJMA) Vol.10, No.6, December 2018

\title{
A Preliminary Survey On Automated SCREENING TOOLS TOWARDS LEARNING DISABILITIES
}

\author{
Roznim Mohamad Rasli ${ }^{1}$, Norita Md Norwawi ${ }^{2}$, Nurlida Basir ${ }^{2}$, \\ Nor Azah Abdul Aziz ${ }^{1}$, Fadhlina Mohd Razali ${ }^{1}$, Siti Aisyah Salim ${ }^{3}$ and \\ Ruziana Mohamad Rasli ${ }^{4}$ \\ ${ }^{1}$ Faculty of Art, Computing and Creative Industry, \\ Sultan Idris Education University, Perak, Malaysia \\ ${ }^{2}$ Department of Information Security and Assurance, \\ Islamic Science University of Malaysia, Nilai, Malaysia \\ ${ }^{3}$ Department of Technology Management, \\ Universiti Tun Hussein Onn, Johor, Malaysia \\ ${ }^{4}$ Department of Information and Communication Technology, \\ Politeknik Tuanku Syed Sirajuddin, Perlis, Malaysia
}

\begin{abstract}
Subsequently, there exist various kinds of screening tools for learning disabilities but most of these screening tools only restricted to static binary output, less attractive, stressful, boring, and time consuming which lead to incomplete activities and unfulfilled objectives. In addition, most of them only targeted on dyslexia, dyscalculia and autism. This preliminary study aims to identify current automated screening tools tailoring for learning disabilities domain. It is guided by several important steps starting from the selection from multiple digital databases (information sources), categorization (study selection), comparison (search and data selection) and summarization of appropriate literature reviews, leading towards a more thorough analysis. Findings indicate that there are various kinds of screening tools available in the market with such different techniques and methods, majorly are interactive and attractive multimedia approaches and artificial intelligence approaches. Thus, the findings are beneficial in the enhancement of future works towards screening and diagnosis in learning disabilities.
\end{abstract}

\section{KEYWORDS}

Screening, Screening Tools, Learning Disabilities

\section{INTRODUCTION}

Screening refers to the presumptive detection of unrecognized or undetected disease of defect done by conducting tests, examinations, or other procedures that will pin point to the probability and the classification of the disease [1-2]. Screening acts as an early intervention and prediction of disease, not intended to be diagnostic and trustable. Thus, further diagnosis and treatment need to be performed in order to support reliable and accurate results. Any positive or suspicious result should to be referred to a psychologist for further diagnosis and intervention [1].

DOI: 10.5121/ijma.2018.10610 
The International Journal of Multimedia \& Its Applications (IJMA) Vol.10, No.6, December 2018 Nowadays, there exist numbers of studies highlighting on the importance of screening tools tailoring for learning disabilities within educational field. The identification and classification of learning disabilities is not an easy task and can only be conducted at least six months after the student started to write, spell and read normally at the early years of schooling in primary school [1]. Generally, the identification of learning disabilities is based on clinical findings, observations or test results. Otherwise, the detection is guided by the developing process, followed by diagnosis completion and educational intervention based on children's externalizing [3].

Early detection can be done based on the clues (probably won't show all of these signs) tend to be identified and most commonly related to primary or elementary school tasks. This is because school focuses on the very things that may be difficult for the children to cope with namely reading, writing, mathematics, listening, speaking, and reasoning. Previous study postulates that approximately $10 \%$ of children face different degrees and types of learning disabilities [3]. Thus, screening tools either manual or computerized are crucial for pre-detection, classification and intervention (remedial measures) for pre-detection, classification and diagnosis of learning disabilities.

In Malaysia, the manual paper-based screening tools are the main approach widely implemented in most schools which is totally conducted by the teachers. This conventional screening tools lead to many drawbacks such as time consuming, less attractive, boring, incomplete tests, and so forth [2]. Obviously, the conventional or manual approach is fraught with problems entailing a better approach.

Such an approach may use the latest computer technology available to develop more advanced screening tools that can generate accurate, fast, and objective results [1], [4]. The current literature is replete with studies employing a dazzling array of technologies and methodologies, such as interactive and attractive multimedia approaches, mobile tools, educational or instructional courseware, simulations, serious game, virtual learning environments, and hybridization techniques for screening and diagnosing of specific learning disabilities. Most of these studies are related with the tacit-to-explicit knowledge conversion since all the knowledge are embedded in domain experts' mind.

Most of the researches try to incorporate the tacit knowledge into an explicit computerized reasoning tools, applications or systems. Thus, a rapid and accurate screening instrument relies on different approaches dependable to its main objectives [5]. However, it must be emphasized that the use of such tools and approaches will not be able to solve all the students' learning problems. On a positive note, some of these tools have been instrumental in helping such students to improve their language and mathematical skills, enhance their learning performance, and increase their motivation, the overall impact of which brings a new, promising hope to them.

This review paper categorizes, compares, and summaries recent automated screening tools tailoring for learning disabilities. It focuses on the general issues and constraints in screening, spreading into the existing automated screening tools in learning disabilities domain. The organization starts with the introduction of screening at a glance, moving in depth towards the methodology being implemented. This is followed by the issues and constraints in screening and automated screening tools for learning disabilities summarized in a table respectively. The conclusion ends up this review paper. 
The International Journal of Multimedia \& Its Applications (IJMA) Vol.10, No.6, December 2018

\section{Methodology}

The findings of this review paper is guided by several important steps starting from the selection, categorization, comparison and summarization of appropriate literature reviews, leading towards a more thorough analysis. The acquisition of related information from appropriate multiple digital database sources is done by a mix of most important keywords comprises of "screening", "screening tools", "screening tests", and "learning disabilities" in different variations, combined by the "OR" operator. Only English literatures (journals and conference articles) are taken into account due to up-to-date and proper scientific works. However, other related sources from books and other type of technical reports are considered if it really matters.

Then, two iterations of screening and filtering are implemented. The first iteration is to excluede duplication and irrelevant articles based on the tiles and abstracts screening. The second iteration filtered the articles based on the thorough full text reading of the pre-screened results from the first one. The same eligibility criteria is used for both iterations.

Particularly, the discussion highlights on the theoretical aspects, techniques including the evolution of screening tools application areas, specifically in learning disabilities domain are preferably filtered and summarized as in Table 1 and Table 2 as follows. The final phase is to summarize the conclusion which ends up this review paper. Figure 1 summaries the overall process comprises of information sources, study selection, search, and data selection process.

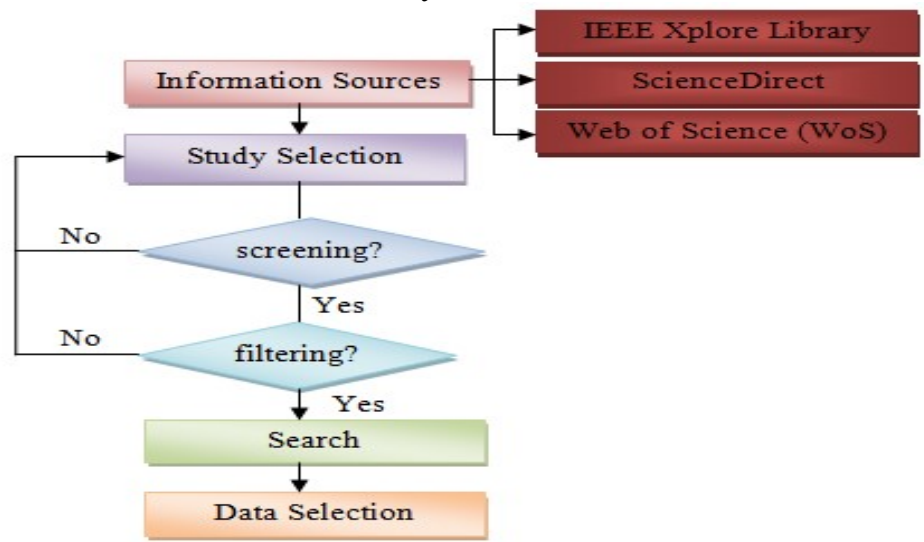

Figure 1. The summarization of overall steps in methodology

\section{ISSUES AND CONSTRAINTS In SCREENING}

Several issues being critic and debate are the variety of symptoms and the nature of the special educational needs, the co-occurrence with other related disorders, the gender differences (boys or girls), which impacted the assessment procedure [6]. Table 1 summaries the issues and constraints of screening and diagnosis specifically for learning disabilities. 
The International Journal of Multimedia \& Its Applications (IJMA) Vol.10, No.6, December 2018

Table 1 . The issues and constraints of screening and diagnosis for learning disabilities

\begin{tabular}{|c|c|}
\hline sues & \\
\hline $\begin{array}{l}\text { No global } \\
\text { method for } \\
\text { learning } \\
\text { disabilities } \\
\text { detection. }\end{array}$ & $\begin{array}{l}\text { - Current works only focus on diagnosing the problem (having or not having) } \\
\text { which is a static binary output [7]. } \\
\text { - Most of the screening tools are too limited to only one type of learning } \\
\text { disabilities, less attractive, stressful, boring, time consuming and long duration } \\
\text { to be completed - lead to incomplete activities and unfulfilled objectives [1],[8]. } \\
\text { - There are works that can correctly classify learning disabilities (dyslexia, } \\
\text { dyscalculia, and dysgraphia), but no intervention included. }\end{array}$ \\
\hline $\begin{array}{l}\text { Conventional } \\
\text { method for } \\
\text { screening and } \\
\text { diagnosis } \\
\text { tailoring } \\
\text { learning } \\
\text { disabilities. }\end{array}$ & $\begin{array}{l}\text { - Screening and diagnosis in most schools in Malaysia are performed manually } \\
\text { (paper-based approach) [1]. } \\
\text { - Human factors (sickness, tiredness, fatigue, stress, lack of interest, emotional } \\
\text { conditions), and other jobs nature and environmental factors can lead to high } \\
\text { possibility of incorrect screening and diagnosis in a timely manner [9-10]. } \\
\text { - Lack of the offered artificial intelligence intervention tools and nationally } \\
\text { regulated standards of its diagnostic methods [6]. } \\
\text { - Difficulty to access screening and diagnosis services especially for rural and } \\
\text { underserved areas. }\end{array}$ \\
\hline $\begin{array}{l}\text { The } \\
\text { knov } \\
\text { acquis } \\
\text { dissen }\end{array}$ & $\begin{array}{l}\text { - A traditional or conventional programs or systems are built both by a mixture of } \\
\text { knowledge and the control structure to process this knowledge, thus leading to } \\
\text { difficulties in understanding and reviewing the program code [11]. } \\
\text { - Extracting and eliciting expert's knowledge is often incomplete with some } \\
\text { defectives and often rationalize, depending on the expert nature, expert } \\
\text { knowledge, and other factors [12]. } \\
\text { - The domain expertise can be extremely busy, can retire, or leave the company } \\
\text { for a host of different reasons. } \\
\text { - The data acquisition only involves the special educators, parents, and doctors, } \\
\text { but the core of learning disabilities which is the student itself is neglected. } \\
\text { - Hard to search since the data and information are bunched up together. } \\
\text { - Ambiguities and uncertainties (uncertain information) and irrelevant and } \\
\text { superfluous variables lead to decrease in diagnosis process time and increase in } \\
\text { accuracy. } \\
\text { - The maintenance of knowledge base requires an amount of time to keep } \\
\text { updating. }\end{array}$ \\
\hline $\begin{array}{r}\text { Other } r \\
\mathrm{fac}\end{array}$ & $\begin{array}{l}\text { - Inadequate number of domain expertise, incomplete and inaccurate screening, } \\
\text { wrong decisions, limited memory capability, low retention of information, } \\
\text { untimely recall of accurate information, and insecure patient records [10]. }\end{array}$ \\
\hline
\end{tabular}

\section{Automated Screening ToOls For Learning DisAbiLities}

Instead of using the conventional manual paper-based approach, an automation of computerizedbased screening tools lead to a better and more precise result, much more objective, time saving and reproducible [1], [4]. In addition it is also the most crucial effort as an alternative approach with special learning method suggested by psychologist [13]. These approaches are part of alternatives not to totally heal them but to suggest an individualized learning strategy and an appropriate intervention due to avoid possible developmental and socio-emotional problems [14]. The results yield to the improvement of their language and mathematical skills, enhance their performance, increase motivation, bring new hope and open a wide new world for them. 
The International Journal of Multimedia \& Its Applications (IJMA) Vol.10, No.6, December 2018 These methods can simulate the real life processes without prior knowledge of the exact relationship between their components. This interactive computerized program transfer, convert, emulate, imitate or reproduce human tacit decision making and reasoning capability process guided by thinking skills, judgemental experience, heuristic knowledge (rules of thumb), intuition and other associated factors. This program is stored in a suitable form, and can be recalled and inferred when necessary. In a much simpler word, it is a focus of concerned of getting computers to perform tasks that requires human intelligence (tacit knowledge) [15].

Whilst in the domain of learning disabilities, subsequently, there exist various kinds of screening tools or screening tests developed to cater learning disabilities based on the effect which varies from one person to another that give drawbacks on every aspects of life. Mostly designed screening tools are targeted to cater learning disabilities like dyslexia and autism. As for example, dyslexia screening tests are specifically developed to measure the probability of dyslexia by using limited information leading to reliable results without the administration and monitoring of experts [4].

Interactive and attractive multimedia approaches are one of the widely implemented approach for screening tools development specifically in educational domain. Multimedia can assist to enhance the accessibility of the learning environment since they have their own role in providing instructions. The justification lies back on the term itself where multimedia elements can attract users especially children with learning disabilities. The typography, supported by audio, video, and animation with appropriate colours, layout and metaphor can assist learning disabilities' sufferer. Whilst the hyperlink and navigation features postulate to a more interactive assessment process without the users realizing them. This is crucial since a better reliable result is achieved by a more natural behaviours shown during the assessment.

As guided by learning disabilities guideline, the typography is based on the font, size and type. San serif is known as the most appropriate font styles due to a clear, straightforward and easy to read typefaces [16]. This leads to a better readability and reading accuracy [17]. The most common one is Arial, ComicSans, Verdana, Tahoma, Century Gothic, Trebuchet, and Helvetica. As for the size, the British Dyslexia Association and the Higher Education Academy have suggested a standardize size is between 12 to 14 points which is suitable for optimal reading [16]. The implementation of two words text in a screen are also beneficial for memory, recognition and recall.

The combination and contrast of colour play an important role in designing and developing the screening tools for learning disabilities since they are very sensitive to brightness. This will impact on their vision where the words appear to swirl or blurt together. As recommended in Human Computer Interaction principle, the good and appropriate contrast should follow the rules of light-dark or dark-light concept (for example: yellow text, dark green background, or black text, white background). The use or green or red should also be avoided since these colours lead to distraction especially for colour blindness people.

The arrangement of layout should also be highlighted, justified to the left with ragged right edges, whilst avoiding narrow columns like newspapers. The line should be in a proper range from 60 to 70 characters, have a start of sentence at the end, and spaced into dense paragraphs (space it out) with 1.5 point line spacing [16]. In addition, the use of bullet points or numbering is much preferable compared to continuous process [18]. As for the metaphor, it need to be related with 
The International Journal of Multimedia \& Its Applications (IJMA) Vol.10, No.6, December 2018 the title, the objectives and existing experiences, leading to a more intuitive interactions and much easier to comprehend [19].

As summarized in Table 2, interactive and attractive multimedia has been commonly implemented in designing and developing screening tools for special needs. Multimedia elements are applied in learning objects to support learning, enhance readiness, improve learnability, gain more understanding and indirectly improve motivation. In addition, the additional value of intervention (remedial measures) can help teachers or educators by proposing educational interventions (strategies, activities and environment), technical intervention (learning packages and voice printing programs) and medical intervention (drug-based theraphy and balanced diets) [17].

Leading towards "Education 4.0", the hybridization of technology is important whereby multimedia can be hybrid with virtual learning, augmented reality or game-based approach to improve teaching and learning strategies. The learning strategies or learning styles should be specifically organized based on the learning environment. However, there are some guidelines that need to be followed to ensure multimedia components are fully exploit namely on how learners learn and different types of learning that already exist. In addition, a meaningful evaluation of multimedia learning object in learning applications need to be integrated into the curriculum [42].

Multimedia has shown promising results in special needs field whereby the integration of multimedia elements such as text, graphic, animation, audio or sound and full motion video can be fully utilized as a focal point to attract participation and attention amongst users. Multisensory engagement can be achieved by using the animation which involves visual, auditory, kinesthetic and tactile. In addition, broken down the content into smaller steps are beneficial for performing short time task, leading to a better learning process [43].

As in artificial intelligence field, knowledge-based systems or expert systems have shown promising results in detecting, predicting and classifying learning disabilities. There are also another approaches used like artificial neural networks, agent-based, intelligent tutoring systems, game-based and many more. 
The International Journal of Multimedia \& Its Applications (IJMA) Vol.10, No.6, December 2018

Table 2. The summarization of screening tools in learning disabilities

\begin{tabular}{|c|c|c|c|}
\hline Method & Application & Description & Findings \\
\hline & i-Dyslex Tool [2] & $\begin{array}{l}\text { - A computer based stand alone system comprises of five main } \\
\text { modules namely "Mendengar", "Membaca", "Berfikir", } \\
\text { "Mengeja", and "Menyusun". } \\
\text { - Main language: Malay language. }\end{array}$ & $\begin{array}{l}\text { - Positive results in term of } \\
\text { similarity to real world, user } \\
\text { control and freedom and } \\
\text { recognition rather than } \\
\text { recall. }\end{array}$ \\
\hline $\begin{array}{c}\text { Interactive } \\
\text { and Attractive } \\
\text { Multimedia } \\
\text { Approach }\end{array}$ & Math Lexic [17] & $\begin{array}{l}\text { - A multimedia mathematical learning aid (multimedia elements } \\
\text { and principles focusing on dyslexia). } \\
\text { - Manipulates multi-presentations and active engagement in real } \\
\text { world environments as well as in formal and informal } \\
\text { mathematical perspectives. } \\
\text { - Objective - to improve dyslexic students' mathematical } \\
\text { understanding and skills by learning through four tutorials and } \\
\text { activities with the assistance of texts and voices. } \\
\text { - The tutorials comprises of Number Recognition } \\
\text { ("KenaliNombor"), Number Sequence ("TurutanNombor"), } \\
\text { Mathematical Symbols ("SimbolMatematik"), and Mathematical } \\
\text { Operations ("OperasiMatematik"). } \\
\text { - The methodology is based on the Usability Engineering Process } \\
\text { Model with three main continuous iteration phases - design, } \\
\text { development and evaluation. }\end{array}$ & $\begin{array}{l}\text { - Easy to use in class and at } \\
\text { home, enhance and support } \\
\text { learning process, improve } \\
\text { student's understanding, } \\
\text { enjoyable, attractive, } \\
\text { supportive. } \\
\text { - Findings are supported by } \\
\text { the User Acceptance Test - } \\
\text { four main criteria; Perceived } \\
\text { Ease of Use (4.63 - 92.6\%), } \\
\text { Perceived Usefulness (4.52- } \\
90.4 \%) \text {, Attitude (4.57- } \\
91.4 \%) \text {, Intention to Use } \\
(4.64-92.8 \%) \text {. }\end{array}$ \\
\hline \multirow{3}{*}{$\begin{array}{l}\text { Interactive } \\
\text { and Attractive } \\
\text { Multimedia } \\
\text { Approach } \\
\text { (continued) }\end{array}$} & 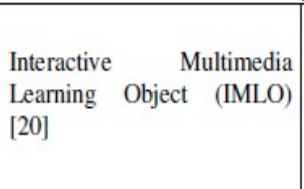 & $\begin{array}{l}\text { - Developed to deliver topic in an interactive story-based form, } \\
\text { adapted from a think-allowed protocol when performing a set of } \\
\text { specific tasks. } \\
\text { - To understand the use of multimedia elements towards learning } \\
\text { support in the field of dyslexia. }\end{array}$ & $\begin{array}{l}\text { Learning by using IMLO is } \\
\text { more effective and enjoyable } \\
\text { for dyslexic children. }\end{array}$ \\
\hline & Smart Lexic [1] & $\begin{array}{l}\text { - Focuses on the integration of interactive multimedia elements } \\
\text { and modality principle (graphics with audio narration) for } \\
\text { dyslexic students. } \\
\text { - Respondents - children aged seven to nine years old. } \\
\text { - The development applied Adobe Flash Professional CS5, Adobe } \\
\text { Photoshop Elements, Microsoft Paint and Audacity 1.3 Beta } \\
\text { software. } \\
\text { - The main language - Malay language, applied in three modules } \\
\text { "Kenalpasti Huruf" (Recognizing Letters), "Kenalpasti Nombor" } \\
\text { (Recognizing Numbers) and "Kenalpasti Arah (Recognizing } \\
\text { Directions). } \\
\text { - Several test questions with variety type of assessments are } \\
\text { presented in form of sound, images, and content outline with } \\
\text { selection of suitable colors, icons, and pictures supported with } \\
\text { minimal wording and drags and drop approaches. } \\
\text { - The acceptance test involves special education teachers - based } \\
\text { on the application's content, navigation, interface design, sound } \\
\text { and general feedback. }\end{array}$ & $\begin{array}{l}\text { - Positive and reliable effect- } \\
\text { multimedia elements can } \\
\text { directly influence and } \\
\text { increase the performance of } \\
\text { the potential dyslexic } \\
\text { students compared to } \\
\text { manual paper-based } \\
\text { screening test method. } \\
\text { - The average percentage of } \\
\text { correct answers is higher } \\
\text { with Smart Lexic }(27.17 \%) \\
\text { compared to conventional } \\
\text { method (20.87\%). } \\
\text { - Mean scores (average of the } \\
\text { scores) of } 4.8 \text { for both of } \\
\text { interesting and valuable, } 4.7, \\
\text { and } 4.5 \text { for enjoyable and } \\
\text { user friendly respectively. }\end{array}$ \\
\hline & Phonological & - An attractive hypermedia application to assist in phonological & - Perform simple navigation \\
\hline
\end{tabular}


The International Journal of Multimedia \& Its Applications (IJMA) Vol.10, No.6, December 2018

\begin{tabular}{|c|c|c|c|}
\hline \multirow{5}{*}{$\begin{array}{l}\text { Interactive } \\
\text { and Attractive } \\
\text { Multimedia } \\
\text { Approach } \\
\text { (continued) }\end{array}$} & Educational Software [21] & $\begin{array}{l}\text { awareness training - integration of multimedia elements (simple } \\
\text { graphics). }\end{array}$ & $\begin{array}{l}\text { and overcome cognitive } \\
\text { overload. }\end{array}$ \\
\hline & $\begin{array}{l}\text { Interactive multimedia } \\
\text { screening approach for the } \\
\text { early screening and detection } \\
\text { of dyslexia [22] }\end{array}$ & $\begin{array}{l}\text { - A Malay Language Reading Courseware - three aspects } \\
\text { (identifying letter, identifying number, and identifying direction) } \\
\text { which incorporates some deficit theories such as directional } \\
\text { confusion. }\end{array}$ & $\begin{array}{l}\text { - Promising results for the } \\
\text { early screening and } \\
\text { detection of dyslexia. }\end{array}$ \\
\hline & Lucid Rapid [23] & $\begin{array}{l}\text { - A computerized assessment software for dyslexia screening. } \\
\text { - The test is conducted in Singapore due to the multilingual society } \\
\text { - phonological processing, auditory sequential memory and } \\
\text { phonic decoding and visual verbal integration memory. } \\
\text { - English proficiency amongst children also impacted this test. }\end{array}$ & $\begin{array}{l}\text { - Accurate prediction results - } \\
\text { overcoming the issue of } \\
\text { false positive and false } \\
\text { negative. }\end{array}$ \\
\hline & E-Z-Disleksia [24] & $\begin{array}{l}\text { - A learning aid tailoring for reading and learning Malay } \\
\text { Language. } \\
\text { - Comprises of: } \\
\text { 1. Content structure (six modules are organized based on levels). } \\
\text { 2. Navigational structure - permit flexibility amongst dyslexic } \\
\text { children to explore the content. } \\
\text { 3. Main menu - index page. } \\
\text { 4. Sub modules - learning content. } \\
\text { 5. Activity - need to follow the animated hand written letter. }\end{array}$ & $\begin{array}{l}\text { - Can accommodate the needs } \\
\text { of dyslexic children with } \\
\text { difficulty reading and } \\
\text { learning Malay language. }\end{array}$ \\
\hline & Dyslexia Mobile Interactive & $\begin{array}{l}\text { - Transfer the dyslexia learning content on Malay verbs into } \\
\text { mobile interactive comic. }\end{array}$ & $\begin{array}{l}\text { - Dyslexic children can learn } \\
\text { a specific topic namely } \\
\text { "verbs" on Malay language }\end{array}$ \\
\hline $\begin{array}{c}\text { Interactive } \\
\text { and Attractive } \\
\text { Multimedia } \\
\text { Approach } \\
\text { (continued) }\end{array}$ & Comic (D-Mic) [25] & & subject. \\
\hline \multirow{3}{*}{$\begin{array}{l}\text { Knowledge- } \\
\text { based Systems } \\
\text { and Expert } \\
\text { Systems }\end{array}$} & $\begin{array}{l}\text { Expert System for Learning } \\
\text { Difficulties (SEDA) [26] }\end{array}$ & $\begin{array}{l}\text { - Focuses on the learning disabilities in children's basic education. } \\
\text { - Equipped with the knowledge base comprising a series of } \\
\text { strategies for Psycho-pedagogy evaluation. } \\
\text { - The process is by identifying the relationships between input } \\
\text { variable (such as age, sex, educational level) and the output } \\
\text { systems (such as psychomotor aspect, intellectual aspect) leading } \\
\text { to the possibility of acknowledge the psychological profile of the } \\
\text { pupil. }\end{array}$ & $\begin{array}{l}\text { - Result yields to } 80 \% \\
\text { acceptance that it is an } \\
\text { efficient expert system using } \\
\text { an estimation scale of Poor, } \\
\text { Moderately Efficient, and } \\
\text { Efficient. }\end{array}$ \\
\hline & $\begin{array}{l}\text { Expert System for Special } \\
\text { Education (ESSE) - based on } \\
\text { Malaysian scenario [27] }\end{array}$ & $\begin{array}{l}\text { - Develop using incremental expert system prototyping model with } \\
\text { the adoption of Qualifiers and Choices. } \\
\text { - The data collected from the observation need to be input by } \\
\text { teacher from time to time into the system in order for the } \\
\text { qualifier to generate results. } \\
\text { - Provides consistent answers for repetitive decisions, processes } \\
\text { and tasks. }\end{array}$ & $\begin{array}{l}\text { - Able to discriminate } \\
\text { between dyslexia and autism } \\
\text { without using multimedia } \\
\text { approach. } \\
\text { - Centralized decision making } \\
\text { with less human errors. }\end{array}$ \\
\hline & $\begin{array}{l}\text { Fuzzy Expert System (using } \\
\text { Java) [7] }\end{array}$ & $\begin{array}{l}\text { - To achieve accurate result with a mass population instead of a } \\
\text { specific small group. } \\
\text { - There are } 11 \text { input units, correspond to } 11 \text { different sections of } \\
\text { curriculum-based test - essay (10), reading (10), comprehension } \\
\text { (10), spelling (10), perception (10), solve (10), word problem }\end{array}$ & $\begin{array}{l}\text { - Able to classify learning } \\
\text { disabilities - dyslexia, } \\
\text { dyscalculia or dysgraphia. } \\
\text { - Simple and easy to replicate } \\
\text { in huge volumes. }\end{array}$ \\
\hline
\end{tabular}


The International Journal of Multimedia \& Its Applications (IJMA) Vol.10, No.6, December 2018

\begin{tabular}{|c|c|c|c|}
\hline \multirow[t]{2}{*}{$\begin{array}{l}\text { Knowledge- } \\
\text { based Systems } \\
\text { and Expert } \\
\text { Systems } \\
\text { (continued) }\end{array}$} & & $\begin{array}{l}\text { - The dataset comprises of } 170 \text { cases of learning disabilities } \\
\text { children acquired from Learning Disabilities Clinics of } \\
\text { Government hospitals in real-time medical environments. }\end{array}$ & $\begin{array}{l}\text { - Good result based on } \\
\text { accepted benchmarks } \\
\text { (training data increase, } \\
\text { overall accuracy shows a } \\
\text { promising growth). }\end{array}$ \\
\hline & \begin{tabular}{|l} 
Fuzzy Expert System \\
{$[28-29]$}
\end{tabular} & $\begin{array}{l}\text { - Uses a collection of fuzzy membership functions and rules and } \\
\text { inferences, rather than using Boolean logic to reason about data. }\end{array}$ & $\begin{array}{l}\text { - Accuracy of approximately } \\
90 \% \text { of classification. }\end{array}$ \\
\hline \multirow{4}{*}{$\begin{array}{l}\text { Artificial } \\
\text { Neural } \\
\text { Networks } \\
(\text { ANN) }\end{array}$} & $\begin{array}{l}\text { Computerized DysDTool } \\
\text { architecture-based on ANN } \\
\text { model [30] }\end{array}$ & $\begin{array}{l}\text { - Built on several layer comprises of web layer to collect } \\
\text { information, data processing layer, ANN layer and screening } \\
\text { module. }\end{array}$ & $\begin{array}{l}\text { - ANN is suitable to screen } \\
\text { dyslexic due to its } \\
\text { robustness characteristic. }\end{array}$ \\
\hline & $\begin{array}{l}\text { Multilayer feedforward } \\
\text { perceptron [31] }\end{array}$ & $\begin{array}{l}\text { - Used to diagnose dyslexia by mapping letter strings to phoneme } \\
\text { strings in multi-syllabic words. } \\
\text { - Better identification rate results in diagnosing learning } \\
\text { disabilities when integrated with different feature selection } \\
\text { algorithms (brute-forte, greedy and genetic algorithm). }\end{array}$ & $\begin{array}{l}\text { - Better identification rate } \\
\text { results. }\end{array}$ \\
\hline & $\begin{array}{l}\text { ANN with an error } \\
\text { backpropogation algorithm } \\
{[32]}\end{array}$ & $\begin{array}{l}\text { - Map college performance to the underlying characteristics. } \\
\text { - The process includes input data of the system based on the test } \\
\text { data covering the evaluation. } \\
\text { - Suggested to be tested on the real data in the future. }\end{array}$ & $\begin{array}{l}\text { Fairly accurate classification } \\
\text { - dyslexic or non-dyslexic. }\end{array}$ \\
\hline & $\begin{array}{l}\text { Simpler Perceptron-based } \\
\text { Learning Disability Detector } \\
\text { (PLEDDOR) [33] }\end{array}$ & $\begin{array}{l}\text { - A hybrid approach of multilayer ANN combined with wavelet } \\
\text { transforms for identifying difficulties in reading (dyslexia), } \\
\text { mathematics (dyscalculia) and writing (dysgraphia) by using } \\
\text { curriculum based test conducted by special educators. } \\
\text { - Formed by a single input layer with } 11 \text { units - correspond to } \\
\text { different sections of a conventional test leading to an output unit. }\end{array}$ & $\begin{array}{l}\text { - Able to diagnose through } \\
\text { pathological voices. } \\
\text { - Simple and easy to replicate } \\
\text { in huge volumes. } \\
\text { - Provides comparable results } \\
\text { based on accepted detection }\end{array}$ \\
\hline \multirow[b]{2}{*}{$\begin{array}{l}\text { Artificial } \\
\text { Neural } \\
\text { Networks } \\
\text { (ANN) } \\
\text { (continued) }\end{array}$} & & $\begin{array}{l}\text { - Involved } 240 \text { respondents (children acquired from schools and } \\
\text { hospitals in India). }\end{array}$ & measures. \\
\hline & $\begin{array}{l}\text { Neuro-fuzzy (hybrid of ANN } \\
\text { and fuzzy logic) [34] }\end{array}$ & $\begin{array}{l}\text { - The model converts the original autistic data into suitable fuzzy } \\
\text { membership values. } \\
\text { - The prediction of autistic disorder is done by a pseudo algorithm } \\
\text { which is created for applying backpropogation algorithm. } \\
\text { - Suggested the use of k-nearest neighbour algorithm for a } \\
\text { comparative research. }\end{array}$ & $\begin{array}{l}\text { - Able to diagnose and predict } \\
\text { autistic disorder (autism). }\end{array}$ \\
\hline $\begin{array}{l}\text { Simple Vector } \\
\text { Machine } \\
\text { (SVM) }\end{array}$ & Simple Vector Machine [35] & $\begin{array}{l}\text { - Serves as a platform for more accurate and less time consuming } \\
\text { diagnosis of ADHD. } \\
\text { - Involves data set that has been verified by doctor including the } \\
\text { questionnaire results used by the doctors to diagnose the } \\
\text { disorder. } \\
\text { - The data set act as an input to the SVM module which is then } \\
\text { returned as an output of the diagnosis. } \\
\text { - Respondents - children aged between } 6 \text { to } 11 \text { years old. }\end{array}$ & $\begin{array}{l}\text { - It can control the complexity } \\
\text { of the diagnostic process. } \\
\text { - Results yield to } 88.674 \% \text { of } \\
\text { success in diagnosing. }\end{array}$ \\
\hline $\begin{array}{c}\text { Learning } \\
\text { Vector } \\
\text { Quantization }\end{array}$ & $\begin{array}{l}\text { Learning } \\
\text { Quantization [7] }\end{array}$ & $\begin{array}{l}\text { - To diagnose whether a student is learning disabled or non- } \\
\text { learning disabled - dyslexia, dysgraphia or dyscalculia. } \\
\text { - After classification being done, a rule-based approach is } \\
\text { implemented to further classify the learning disabilities. }\end{array}$ & $\begin{array}{l}\text { - Able to diagnose either } \\
\text { dyslexia, dysgraphia or } \\
\text { dyscalculia. }\end{array}$ \\
\hline $\begin{array}{c}\text { Digital Signal } \\
\text { Processing }\end{array}$ & \begin{tabular}{|lll} 
Digital Signal & Processing \\
{$[36]$} & & \\
\end{tabular} & $\begin{array}{l}\text { - Used to diagnose learning disabilities for dyslexia detection - } \\
\text { comparing pre-recorded and properly pronounced phonemes } \\
\text { with mispronounced phonemes. }\end{array}$ & $\begin{array}{l}\text { - The results lead to the } \\
\text { detection of dyslexic } \\
\text { students based on the } \\
\text { analysis of the spoken and }\end{array}$ \\
\hline
\end{tabular}


The International Journal of Multimedia \& Its Applications (IJMA) Vol.10, No.6, December 2018

\begin{tabular}{|c|c|c|c|}
\hline & & & written words. \\
\hline $\begin{array}{l}\text { Fuzzy } \\
\text { Cognitive } \\
\text { Maps }\end{array}$ & Fuzzy cognitive maps [37] & $\begin{array}{l}\text { - Formed by the synergy of fuzzy logic and ANN methodologies, } \\
\text { based on the exploitation of integrated experience of expert- } \\
\text { scientists. } \\
\text { - The symbolic representation is guided by a signed, weighted } \\
\text { graph with feedback comprises of nodes and weighted arcs. } \\
\text { - Applied for differential diagnosis of specific language } \\
\text { impairment from the dyslexia and autism. } \\
\text { - To overcome the problems where the symptoms has been } \\
\text { confused with severe cases of dyslexia and mild cases of autism. } \\
\text { - Genetic algorithm also has been hybridization with Fuzzy } \\
\text { Cognitive Map for better accurate diagnosis. }\end{array}$ & $\begin{array}{l}\text { - Tested on four clinical cases } \\
\text { with promising results - the } \\
\text { reported trials fully verified } \\
\text { the effectiveness of the } \\
\text { model. } \\
\text { - A sufficient estimation } \\
\text { model that reliably assist the } \\
\text { speech pathologist in cases } \\
\text { of language and } \\
\text { communication disorders. }\end{array}$ \\
\hline \multirow{3}{*}{$\begin{array}{l}\text { Intelligent } \\
\text { Tutoring } \\
\text { Systems }\end{array}$} & LaTex [38] & $\begin{array}{l}\text { - An assistive technology for terminology, symbolism and graphic } \\
\text { representation. } \\
\text { - Matched each mathematical object accordingly in mathematical } \\
\text { language by using a speech synthesizer. }\end{array}$ & $\begin{array}{l}\text { Helpful for school } \\
\text { homework completion - } \\
\text { facilitates both teachers and } \\
\text { students. }\end{array}$ \\
\hline & Spatial Math Tutor & $\begin{array}{l}\text { - Developed, tested and implemented into an online tutoring } \\
\text { environment to cater difficulties in mathematical skills. } \\
\text { - Presented in a graphical representation with the manipulation of } \\
\text { computer graphic objects, assistive three dimensional (3D) } \\
\text { graphic technology and interaction tutoring. }\end{array}$ & $\begin{array}{l}\text { - It mimics the traditional } \\
\text { face-to-face interaction - } \\
\text { beneficial for problematic } \\
\text { students. }\end{array}$ \\
\hline & $\begin{array}{l}\text { Repeated Reading Adaptive } \\
\text { Fluency Tutor }\end{array}$ & $\begin{array}{l}\text { - Designed and developed to improve reading fluency purpose } \\
\text { among dyslexic students. }\end{array}$ & \begin{tabular}{|l} 
- It educates students on \\
appropriater decoding \\
patterns and motivates them.
\end{tabular} \\
\hline \multirow{2}{*}{$\begin{array}{l}\text { Gamification } \\
\text { Approach }\end{array}$} & $\begin{array}{l}\text { Gamification training tool } \\
\text { (serious game) [39] }\end{array}$ & $\begin{array}{l}\text { - Comprises of series of game - Paths game, Fence letter game and } \\
\text { the Wizard game objectively to test the visual and auditory } \\
\text { processing. } \\
\text { - One of the elements being evaluated is the Temporal Order } \\
\text { Judgment. }\end{array}$ & $\begin{array}{l}\text { - To predict the risk of } \\
\text { developmental dyslexia in } \\
\text { pre-readers children and to } \\
\text { treat them. }\end{array}$ \\
\hline & $\begin{array}{l}\text { Web-based game approach } \\
\text { with the client-server } \\
\text { architecture [40] }\end{array}$ & $\begin{array}{l}\text { - Six different games purposely to evaluate the student word } \\
\text { production, syllabic memory capacity, verbal work memory, } \\
\text { auditory memory syllable, and word reading capacity. }\end{array}$ & $\begin{array}{l}\text { - Children will achieve the } \\
\text { statistical results once they } \\
\text { completed the game. } \\
\text { - } 100 \% \text { children } \\
\text { independently. }\end{array}$ \\
\hline $\begin{array}{l}\text { Agent-based } \\
\text { Approach }\end{array}$ & $\begin{array}{l}\text { An open agent-based } \\
\text { framework [41] }\end{array}$ & $\begin{array}{l}\text { - Adaptable e-learning environment to achieve personalized e- } \\
\text { learning facilities for dyslexic students. } \\
\text { - Supports automated ontology-based learning facilities production } \\
\text { composition and use, including management reuse and retrieval } \\
\text { of external resources. } \\
\text { - It comprises of knowledge expert agent, teacher agent, dyslexic } \\
\text { learner personal agent, collaboration agent, evaluator agent, } \\
\text { ontology search agent, web-search agent, mapping, annotation } \\
\text { agent and external resource agent. }\end{array}$ & $\begin{array}{l}\text { - The design of a reuse } \\
\text { platform ensures an effective } \\
\text { and efficient e-learning } \\
\text { environment - uses } \\
\text { capabilities of semantic and } \\
\text { agent-based technologies (to } \\
\text { achieve flexibility and semi- } \\
\text { automation). }\end{array}$ \\
\hline
\end{tabular}

\section{CONCLUSION}

All the issues have concluded that the initial years of learning are crucial for children to build up fundamental understanding towards theirs upcoming mental developmental processes. Hence, early screening is required to detect any signs or symptoms of learning disabilities during normal classroom-beased teaching episodes. Advances in technology, specifically artificial intelligence have demonstrated that screening tools can be integrated to assit in pre-screening and pre- 
The International Journal of Multimedia \& Its Applications (IJMA) Vol.10, No.6, December 2018 detection of learning disabilities from multiple perspectives and also enabling special educators or parents to well-understand their exact conditions. Knowledge-based systems, intelligent tutoring systems, artifical neural networks, agent-based approach, gamificatian approach and interactive and attractive multimedia approach are part of methods and technologies which have been beneficial to educational fields especially in learning disabilities domain. The screening tools integration more or less has improved the early screening process in a much easier and more reliable ways. Whatever it is, to bear in mind that the integration of screening tools is not and never will be transformative on its own, thus the support and collaboration of all engines in educational fields namely educators, administrators, policy makers, district, state, and ministry of education are crucial towards the successful implementation of it. The findings can help provide greater insights into the understanding of screening and learning disabilities, which can further improve the current practice of practitioners and enrich the body of knowledge, benefiting researchers, eduactors, parents, students and so forth.

\section{REFERENCES}

[1] Mohd Ekhsan, H., Ahmad, S. Z., Abdul Halim, S., Hamid, J. N., \& Mansor, N. H (2012). The implementation of interactive multimedia in early screening of dyslexia. Paper presented at the 2012 International Conference on Innovation Management and Technology Research, Malacca, Malaysia.

[2] Wan Isa, W. M., Wan Shamsuddin, S. N., Nik Mat, N. S. F., Makhtar, M., Mohamad, F. S., \& Husain, R. (2017). Heuristic evaluation of i-Dyslex tool for dyslexia screening. Journal of Telecommunication, Electronic and Computer Engineering, 9(2-4), pp. 15-19.

[3] Xu, Y., Li, H., \& Wang, H. (2011). Knowledge representation and design about expert system for learning disability check for children. IT in Medicine and Education (ITME), 2011 International Symposium, 2, pp. 567-570.

[4] Bocklet, T., Winterholler, C., Maier, A., Schuster, M., \& Noth, E. (2009). An automatic screening test for preschool children: theory and data collection. Paper presented at the Proceedings of the ACM 2nd Workshop on Child, Computer and Interaction, New York, USA.

[5] Pee, N. C., Sibgatullah, A. S., \& Mohtaram, S. (2014). Mobile dyslexia screening test: A new approach through (multiple deficit) model mobile game to screen developmental dyslexia children. Paper presented at the 8th MUCET 2014, Malacca, Malaysia.

[6] Drigas, A. S \& Ioannidou. R. E. (2011). A review on artificial intelligence in special education. Paper presented at the World Summit on Knowledge Society (WSKS 2011), Mykonos, Greece.

[7] Manghirmalani, P., More, D., \& Jain, K. (2012). A fuzzy approach to classify learning disability. International Journal of Advanced Research in Artificial Intelligence, 1(2), pp. 1-7.

[8] Pohradsky, P., Londak, J., \& Ac Ikova, M. C. (2010). Application of ICT in Pre-school Education. Paper presented at the Proceedings ELMAR-2010, Zadar, Croatia.

[9] Al-Riyami, A., Al-Amri, A. A. K., \& Al-Busaidi, K. A. (2014). Zakat expert system. Paper presented at the Proceedings of the 15th European Conference on Knowledge Management (ECKM 2014), Santarem, Portugal.

[10] Akinyokun, O. C., Iwasokun, G. B., Arekete, S. A., \& Samuel, R. W. (2015). Fuzzy logic-driven expert system for the diagnosis of the heart failure disease. Artificial Intelligence Research, 4(1), pp. $12-21$.

[11] Tripathi, K. P. (2011). A review on knowledge-based expert system: concept and architecture. IJCA Special Issue on "Artificial Intelligence Techniques - Novel Approaches \& Practical Applications", pp. 19-23.

[12] Mohammad, A. H., \& Al Saiyd, N. A. M. (2012). Guidelines for tacit knowledge acquisition. Journal of Theoretical and Applied Information Technology, 38(1), pp. 110-118.

[13] Wan Shamsuddin, S. N., Nik Mat, N. S. F., Makhtar, M., \& Wan Isa, W. M. (2017). Classification techniques for early detection of dyslexia using computer-based screening test. World Applied Sciences Journal, 35(10), pp. 2108-2112. 
The International Journal of Multimedia \& Its Applications (IJMA) Vol.10, No.6, December 2018

[14] Drigas, S., \& Kokkalia, G. K. (2017). Intervention and diagnostic tools in preschool education. iJET, 12(11), pp. 185-197.

[15] Folorunso, I. O., Abikoye, O. C., Jimoh, R. G., \& Raji, K. S. (2012). A rule-based expert system for mineral identification. Journal of Emerging Trends in Computing and Information Sciences, 3(2), pp. 205-210.

[16] Aziz, F. A., Husni, H., \& Jamaludin, Z. (2013). Translating interaction design guidelines for dyslexic children's reading application. WCE, II, pp. 3-6.

[17] Ahmad, S. Z., Jinon, N. I., \& Rosmani, A. F. (2013). Math Lexic: An assistive multimedia mathematical learning aid for dyslexia children. Paper presented at the 2013 IEEE Business Engineering and Industrial Applications Colloquium (BEIAC 2013), Langkawi, Malaysia.

[18] Nik Mat, N. S. F., Wan Shamsuddin, S. N., Husain, R., Makhtar, M., Wan Isa, W. M., \& Mohamad, F. S. (2014). A conceptual framework for designing a computer-based dyslexia screening test. Paper presented at Proceedings of the Third International Conference on Informatics \& Applications, pp. 46-50.

[19] Azizah, C. N., Mutalib, A. A., Aziz, N., \& Abu Bakar, R. M. (2011). Multiple intelligence ensures usability of digital storytelling for preschool children. Paper presented at Proceedings of the International Conference on Advanced Science, Engineering and Information Technology, ISBN 97842366-4-9.

[20] Abtahi, M. S. (2012). Interactive Multimedia Learning Object (IMLO) for dyslexic children. Procedia-Social and Behavioral Sciences, 47(2012), pp. 1206-1210.

[21] Kazakou, M., Soulis, S., Morfidi, E., \& Mikropoulos, T. A. (2011). Phonological awareness software for dyslexic children. Themes in Science and Technology Education, 4(1), pp. 63-67.

[22] Mahidin, E., Umar, K., Ismail, S., Ismail, R., \& Mohd Yusoff, M. Z. (2011). Preliminary testing on interactive Bahasa Melayu reading courseware for dyslexic children. Paper presented at the 2011 2nd International Conference on Education and Management Technology IPEDR, Singapore.

[23] Brookes, G., Ng, V., Lim, B. H., Tan, W. O., \& Lukito, N. (2011). The computerized-based Lucid Rapid dyslexia screening for the identification of children at risk of dyslexia: a Singapore study. Educational Child Psychology, 28(2), pp. 33-51.

[24] Ismail, S. S., Ismail, M. M., Umar, M. Z., \& Mohd Yusoff. (2010). E-Z-Disleksia for dyslexic children. Paper presented at Proceedings of Regional Conference on Knowledge Integration in ICT. Putrajaya, Malaysia.

[25] Umar, R. S., Abdul Rahman, F., \& Mokhtar. (2010). D-Mic: A mobile learning application for dyslexic children. Malaysian Journal of Mobile Learning, 1(1), pp. 1-15.

[26] Hernadez, J., Mousalli, G., \& Rivas, F. (2009). Learning difficulties diagnosis for children's basic education using expert systems. WSEAS Transaction on Information Science and Applications, 7(6), pp. n.d.

[27] Mohd Yusoff, N., Abdul Wahab, M. H., Aziz, M. A., \& Asha'Ari, F. J. (2009). ESSE: Learning disability classification system for autism and dyslexia. Paper presented at the International Conference on Universal Access in Human Computer Interaction, Berlin, Heidelberg.

[28] Singh, A., \& Solanki, A. (2013). Dynamic knowledge acquisition process of online fuzzy disease diagnosis expert system for home pets. International Journal of Computer Science Engineering (IJCSE), 2(5), pp. 262-270.

[29] Jain, L., Kumar, H., Singla, R. K., Singh, P., \& Lore, J. S. (2014). Error reduction in promoted confidence factor of a rule using improved fuzzy rule promotion technique. Cybernatics and Information Technologies, 14(1), pp. 72-83.

[30] Costa, M., Zavaleta, J., Da Cruz, S. M. S, Manhaes, M., Cerceau, R., Carvalho, L. A., \& Mousinho, R. (2013). A computational approach for screening dyslexia. Paper presented at the 2013 IEEE 26th International Symposium on Computer-Based Medical Systems (CBMS 2013), Porto, Portugal.

[31] Wu, T. K., Meng, Y. R., \& Huang, S. C. (2006). Application of Artificial Neural Network to the Identification of Students with learning disabilities. Paper presented at the IC-AI.

[32] Kohli, M., \& Prasad T. V. (2010). Identifying dyslexic students by using Artificial Neural Networks. Paper presented at the Proceedings of the World Congress on Engineering 2010, London, United Kingdom. 
The International Journal of Multimedia \& Its Applications (IJMA) Vol.10, No.6, December 2018

[33] Jain, K., Manghirmalani, P., Dongardive, J., \& Abraham, S. (2009). Computational diagnosis of learning disability. International Journal of Recent Trends in Engineering, 2(3), pp. n.d.

[34] Arthi, K., \& Tamilasari, A. (2008). Prediction of autistic disorder using neuro fuzzy system by applying ANN technique. International Journal of Developmental Neuroscience, 26, pp. 699-704.

[35] Anuradha, J., Tisha Ramachandran, V., Arulalan, K. V., \& Tripathy, B. K. (2010). Diagnosis of ADHD using SVM algorithm. Paper presented at the Proceedings of the Third Annual ACM Bangalore Conference, Bangalore, India.

[36] Reitano, C. T. (2003). System and Method for Dyslexia Detection by Analyzing Spoken and Written Words. United States Patent US 6535853 B1.

[37] Georgopoulos V. C, \& Stylios, C. D. (2008). Genetic algorithm enhanced fuzzy cognitive maps for medical diagnosis. Paper presented at the 2008 IEEE International Conference on Fuzzy Systems (IEEE World Congress on Computational Intelligence), Hong Kong, China.

[38] Drigas, A., \& Dourou, A. (2013). A review on ICTs, e-learning and artificial intelligence for dyslexic's assistance. I-JET, 8(4), pp. 63-67.

[39] Gaggi, O., Galiazzo, G., Palazzi, A., Facoetti, A., \& Franceschini, S. (2012). A serious game for predicting the risk of developmental dyslexia in pre-readers children. Paper presented at the 201221 st International Conference on Computer Communications and Networks (ICCCN 2012), Munich, Germany.

[40] Bartolome, N. A., Zorilla, A. M., \& Zapirain, B. G. (2012). Dyslexia diagnosis in reading stage through the use of games at school. Paper presented at the Proceedings of the 2012 17th International Conference on Computer Games: AI, Animation, Mobile, Interactive Multimedia, Educational and Serious Games (CGAMES), Washington DC, USA.

[41] Ivanova, T., Andreev, R., \& Terzieva, V. (2010). Integration of ontology with development of personalized e-learning facilities for dyslexics. Paper presented at the International Conference on Artificial Intelligence: Methodology, Systems and Applications, Berlin, Heidelberg.

[42] McEwan, T., \& Cairncross, S. (2004). Evaluation and multimedia learning objects: towards a humancentred approach. Interactive Technology and Smart Education, 1(2), pp. 101-112.

[43] Abdul Rahman, F., \& Mokhtar, F. (2009). Dyslexic children learning styles. Paper presented at Proceedings:3rd International Malaysia Educational Technology Convention, Batu Ferringhi, Penang, Malaysia 2009, pp. 21-26. 
The International Journal of Multimedia \& Its Applications (IJMA) Vol.10, No.6, December 2018

\section{AUTHORS}

Roznim Mohamad Rasli is a lecturer at Faculty of Art, Computing and Creative Industry, Sultan Idris Education University (UPSI). Her research interest is in Artificial Intelligence, Knowledge-based Systems, Knowledge Management, Data Mining/Knowledge Discovery in Databases, and Multimedia Interactive.

Norita Md. Norwawi is a professor at Faculty of Science and Technology. She is also a Director of Islamic Science Institute, Islamic Science University of Malaysia (USIM). Her research interest is in Temporal Data Mining, Multi-agent Systems and Artificial Intelligence.

Nurlida Basir is an associate professor at Faculty of Science and Technology, Islamic Science University of Malaysia (USIM). Her research interest is in Software Engineering.

Nor Azah Abd Aziz is an associate professor at Faculty of Art, Computing and Creative Industry, Sultan Idris Education University (UPSI). Her research interest is in Gestural Interface Design, Child Computer Interaction, Multimedia Application Development, Islamic Spiritual Psychology, Information Technology, Internet / Web Filtering and Internet and Society.

Fadhlina Mohd Razali is a lecturer at Faculty of Art, Computing, and Creative Industry, Sultan Idris Education University (UPSI). Her research interest is in ChildComputer Interaction, Multimedia Application Development, Gestural Interface Design, Gamification and Early Childhood Education.

Siti Aisyah Salim is a senior lecturer at Faculty of Technology Management, Universiti Tun Hussein Onn Malaysia (UTHM). Her research interest is in Knowledge Management, Database Management, Enterprise System, Cloud ERP, Innovation Adoption, Organisational Decision Making, and Multi-group.

Ruziana Rasli is a lecturer at Department of Information and Communication Technology, Politeknik Tuanku Syed Sirajuddin. Her research interest is in Software Engineering, Semantics and Ontology.
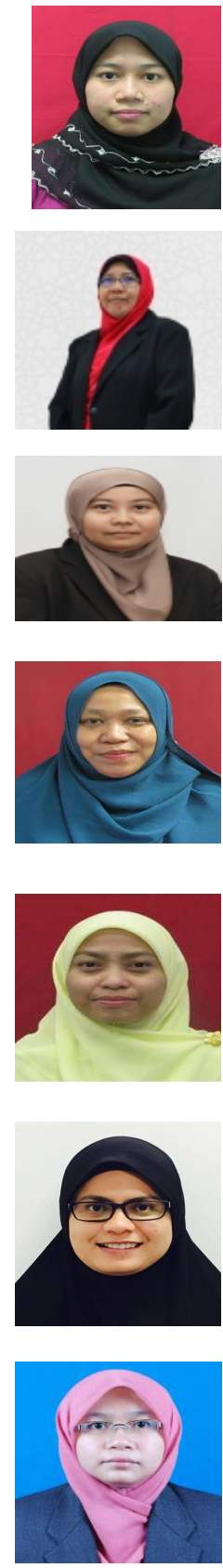